\title{
Treatment of Parapelvic Cyst by Internal Drainage Technology Using Ureteroscope and Holmium Laser

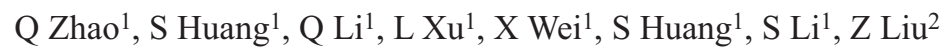

\begin{abstract}
Background: The aim of parapelvic cyst treatment is to have complete drainage of cyst fluid and prevent its further compression of the kidney and collective system. This study explores the efficacy and safety of surgical approaches with holmium laser ureteroscopic internal drainage in the treatment of parapelvic cyst.

Methods: The compression effect of parapelvic cyst on the renal collective system was observed by rigid ureteroscope using retrograde ureteroscopic technology. With direct vision, the cyst wall on the obvious parapelvic compression site was cut. The diameter of the cyst wall cut was about $1 \mathrm{~cm}$. The internal drainage was obtained by double-J tubes. When the cyst was in the inferior pole of kidney or where the rigid ureteroscope could not reach, a flexible ureteroscope was used.

Results: In 28 cases of operation, 27 cases were successful. The cyst treatment time was eight to $40 \mathrm{~min}$ utes (average 26 minutes). During the operation, no massive haemorrhage, damage of nearby organ and ureter, or other complications happened. Time of follow-up was 10-72 months (average 39 months). The results of follow-up showed that in 22 cases, the cyst disappeared; the diameter of the cyst in four cases was reduced by more than half, and one case recurred.

Conclusion: The treatment of parapelvic cyst by internal drainage operation using holmium laser and ureteroscopy was effective. The operation was safe with few complications.
\end{abstract}

Keywords: Holmium laser, parapelvic cyst, ureteroscopy

\section{Tratamiento del Quiste Parapélvico Mediante Tecnología de Drenaje Interno Usando Ureteroscopio y Láser de Holmio

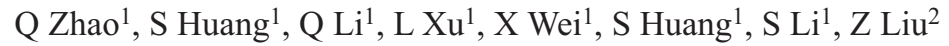

\begin{abstract}
RESUMEN
Antecedentes: El objetivo del tratamiento de quiste parapélvico es lograr el drenaje completo del líquido del quiste y prevenir su compresión ulterior del riñón y el sistema colectivo. Este estudio explora la eficacia y seguridad de los abordajes quirúrgicos cn drenaje interno mediante ureteroscopia con láser de holmio en el tratamiento de quiste parapélvico.

Métodos: El efecto de la compresión del quiste parapélvico del sistema colectivo renal fue observado mediante ureteroscopio rígido utilizando la tecnología ureteroscópica retrógrada. Con visión directa, la pared del quiste fue cortada en el sitio obvio de la compresión parapélvica. El diámetro de la pared del quiste cortada era alrededor de $1 \mathrm{~cm}$. El drenaje interno se obtuvo con catéteres doble J. Cuando el quiste estaba en el polo inferior del riñón o donde no podía llegar el ureteroscopio rígido, se utilizaba un ureteroscopio flexible.

Resultados: De 28 casos de operación, 27 casos tuvieron éxito. El tiempo de tratamiento del quiste fue de ocho a 40 minutos (un promedio de 26 minutos). Durante las operaciones, no hubo hemorragias masivas, daños de órganos y uréteres, u otras complicaciones. El tiempo de seguimiento fue de 10 a 72 meses (un promedio de 39 meses). Los resultados del seguimiento mostraron que en 22 casos, el quiste
\end{abstract}

From: ${ }^{1}$ Department of Urology, Shandong Provincial Qianfoshan Hospital, Shandong University, Jinan 250014, China and ${ }^{2}$ Department of Urology, Qilu Hospital, Shandong University School of Nursing, Shandong University, Jinan 250012, China.
Correspondence: Dr Z Liu, Department of Urology, Qilu Hospital, Shandong University, 107 Wenhua Xi Road, Jinan 250012, China. Fax: +86-53182166711; e-mail: Drliu2014@163.com 
desapareció. En cuatro casos, el diámetro del quiste se redujo en más de la mitad, y reapareció en uno de los casos.

Conclusión: El tratamiento de quiste parapélvico por operación de drenaje interno con láser de holmio y ureteroscopia fue eficaz. La operación fue segura con pocas complicaciones.

Palabras claves: Láser de holmio, quiste parapélvico, ureteroscopia

West Indian Med J 2015; 64 (3): 231

\section{INTRODUCTION}

The kidney is prone to cystic lesions. Usually, the incidence is about $25 \%$ in adults older than 40 years and this value increases to $66 \%$ when the adult is older than 80 years (1). When the cyst occurs near the renal pelvis or pedicle, it is called a parapelvic cyst. A parapelvic cyst is a non-genetic cyst with pathological changes; the incidence is about $1 \%-2 \%$ of total renal cysts (2). The mechanism and tissue structure of parapelvic cyst is almost the same as the simple kidney cyst. Generally, the cause of this disease is either as a result of congenital dysplasia or acquired obstruction in the kidney. The parapelvic cyst is related to urinary tract obstruction. The patient with this condition usually has a medical history of urinary tract obstruction, concretion, or infectious disease. Some researchers consider that this is due to the local expansion of pelvic lymphatic vessels caused by chronic inflammation $(3,4)$. The greater parapelvic cysts could lead to compression on the renal pelvis, vessels and lymphatic vessels. More seriously, this could lead to severe uronephrosis, renovascular hypertension or kidney failure. The most common clinical features of this disease include pain (98\%), urinary tract infection $(9.5 \%)$ and haematuria [4.8\%] (5).

The aim of parapelvic cyst treatment is to have complete drainage of cyst fluid and prevent its further compression on the kidney and collective system. In 1991, Kavoussi et al reported the first successful example of peripelvic cyst treatment by ureteroscope retrograde ostomy (6). However, there are not enough numbers and sufficient follow-up period in published studies. In this paper, a series of experience of parapelvic cyst treatment by internal drainage technology using holmium laser and ureteroscope is reported.

\section{SUBJECTS AND METHODS}

The patients in this study came from Fo-Shan Hospital in Shandong Province beween August 1996 and October 2011. Overall, the number of patients with parapelvic cyst was 28 , and included 11 men and 17 women. Among these cases, four had multiple cysts while others had single cysts. The diameters of the cysts were $0.5-7.8 \mathrm{~cm}$, and the average diameter was $4.8 \mathrm{~cm}$. Clinically, 25 cases $(89.3 \%)$ had lumbago; two cases $(7.1 \%)$ had colic; three cases had a history of haematuria observed by laparoscope; four cases had a history of hypertension; three cases had no obvious clinical signs and were detected during medical examination; and four cases were misdiagnosed as uronephrosis. The cases in this study had the normal values for blood urea nitrogen (BUN) and creatinine (Cr). Type-B ultrasonography, computed tomography (CT) and intravenous urography were used for checking and making a definite diagnosis. Enhancement CT and three-dimensional reconstruction showed that the renal pelvis and renal calyces were compressed; moreover, the excretory phase contrast agent could not enter the cyst; also, the space between the cyst wall and collective system had no other tissues (Figs. 1 and 2). The patients who had renal calculus and ureteric operations were excluded. All the patients were told about the operation risk and they signed an informed consent.

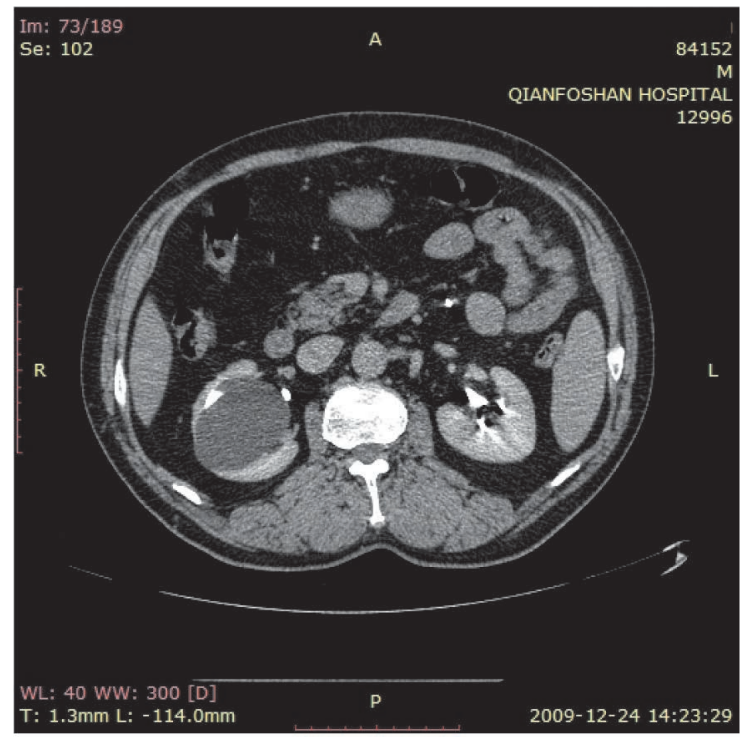

Fig. 1: The space between the cyst wall and collective system.

The Poversuite-100 holmium laser system (Lumenis Corporation, USA; $365 \mu \mathrm{m}$ or $200 \mu \mathrm{m}$ end-fire optical fibre, laser wave length $2140 \mathrm{~nm}$ ), F8/9.8 Wolf rigid ureteroscope, and the Olympus ORF-P3 fiberoptic flexible ureteroscope were used in this study.

Epidural anaesthesia or general anaesthesia was used and patients were in the lithotomy position. Then, the F8/9.8 Wolf rigid ureteroscope was entered into the renal pelvis retrogradely and the compression of the parapelvic cyst on the collective system was observed. The cyst wall with obvious compression mark observed by CT before the operation was cut by $365 \mu \mathrm{m}$ holmium laser. When the cyst was confirmed, the cut was expanded to remove the cyst wall with about $1 \mathrm{~cm}$ diameter. Then, the cyst was connected with the collective sys- 


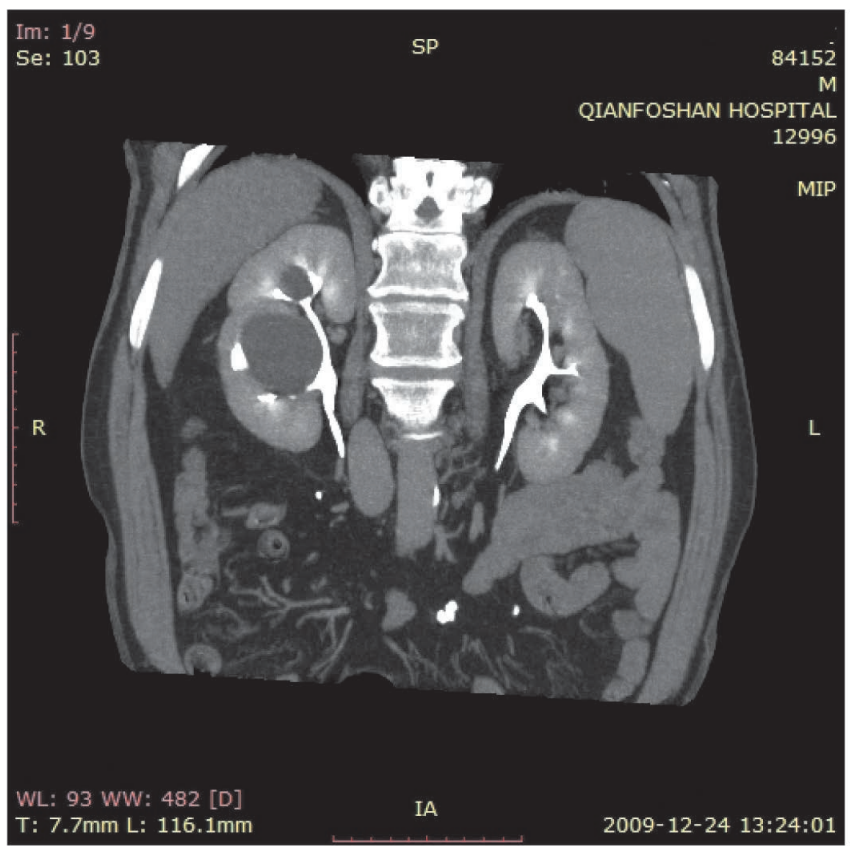

Fig. 2: Compression on the collective system.

tem, and the ureteroscope was entered into the cyst to completely inspect its interior to avoid the misdiagnosis of cystic renal-cell carcinoma. If the cyst had septation, then this was cut (Fig. 3A-E).
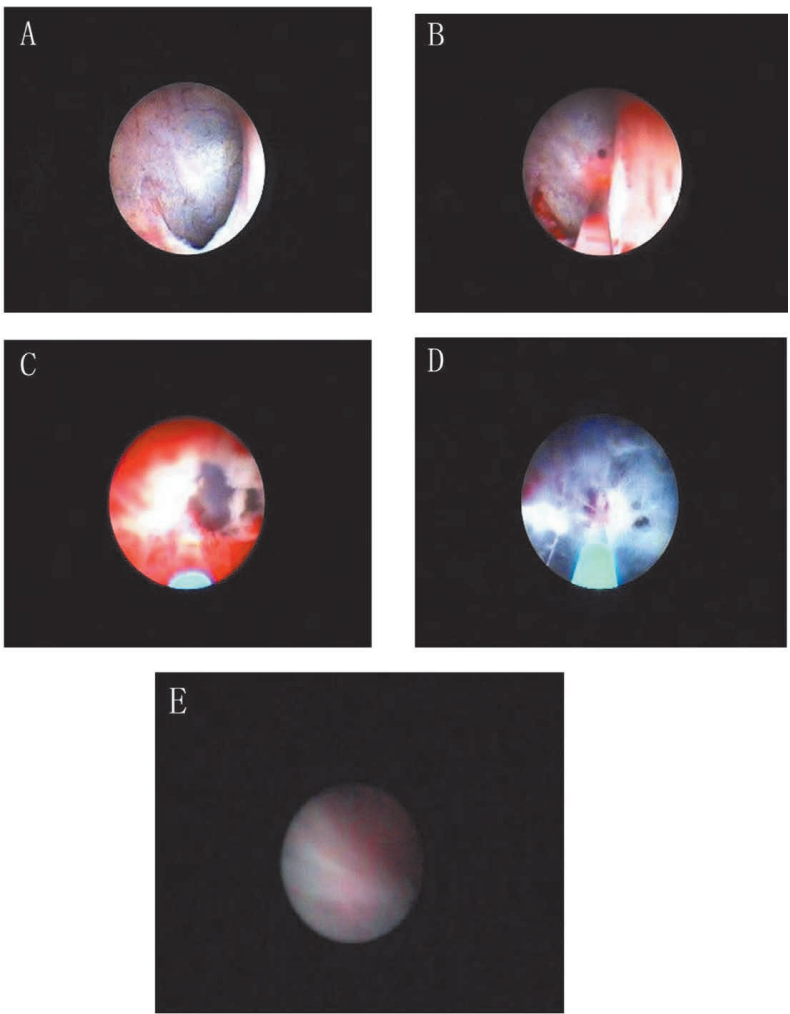

Fig. 3: The process of operation. (A) The part of parapelvic cyst was blue; (B) the parapelvic cyst was excised by holmium laser; (C) part of the cyst was excised; (D) the separation in the cyst was excised; (E) the cyst wall was observed by ureteroscopy by getting into the cyst.
The inferior pole of the kidney or the place that the ureteroscope could not reach was operated on by flexible ureteroscopy and $200 \mu \mathrm{m}$ holmium laser. The $5 \mathrm{~F}$ double-J tube was set by ureteroscope, and its proximal end was in the cyst. Whether the 5F double-J tube was set in cyst or not was observed by $\mathrm{CT}$ and plain abdominal radiograph about one week after the operation (Fig. 4). Eight weeks after the operation, the double-J tube was removed. Three months after the operation, the patients were checked by type-B ultrasonography, CT, routine blood test, routine urine test and blood biochemical tests.

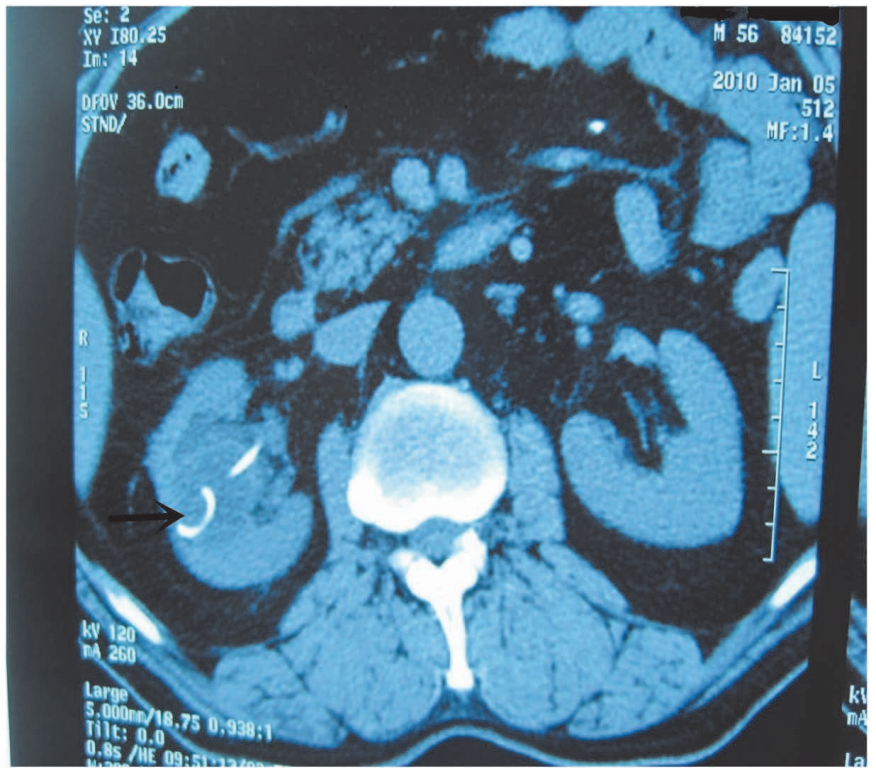

Fig. 4: One week after operation, the double-J tubes were placed in the cyst.

\section{RESULTS}

For the total of 28 cases, one case could not to be operated on by ureteroscope because of the narrow ureter and was operated on by celoscope instead. Among the successful cases, 25 were operated on by rigid ureteroscope while two others were operated on by flexible ureteroscopy because the cyst was in the inferior pole of the kidney or the rigid ureteroscope could not reach it. The operation time ranged from 30 to $101 \mathrm{~min}-$ utes and the average operation time was 58 minutes. The cyst treatment time ranged from eight to 40 minutes, and the average time was 26 minutes. During the operation, there was no massive haemorrhage, damage to nearby organ or ureter or other serious complications. In one case of a cyst (diameter $0.5 \mathrm{~cm}$ ) in the upper pole of the kidney, haemorrhage was in the renal parenchyma beside the cyst and was caused by the holmium laser and staunching by the holmium laser had no effect. To handle this situation, perfusion flow pressure was increased and after 15 minutes, the haemorrhage was stopped. After the operation, no serious haematuria, urine leak and obvious infection occurred. The catheter was left for one to four days and patients left the hospital three to six days after operation, in general. 
The 27 patients were followed-up after operation. The time of follow-up lasted from 10 to 72 months, with an average time of 39 months. The content of follow-up included signs, symptoms, laboratory tests and imaging examination (CT or type-B ultrasonography). Among the 25 patients who had lumbago, symptoms had disappeared or were relieved in 23. Among the three patients who had haematuria, symptoms disappeared in two cases, and blood pressure normalized in three of the four cases that had hypertension. After the removal of the double-J tube, no haematuria and infection was observed, biochemical and routine blood tests were normal and there was no albuminuria.

During the period of follow-up, no urinary calculus or tumour was seen. The cysts disappeared, the compression of the cyst on the collective system was relieved, and the kidney recovered its normal shape in 22 of the 27 cases (Fig. 5). For the other five cases, the diameter of the cyst was reduced by more than $50 \%$ compared with that before the operation in four cases; the cyst recurred in one case at about 60 months, to the size prior to the operation. On review with the operation imaging, this might have occurred from the uncompleted excision of the partition inside the cyst.

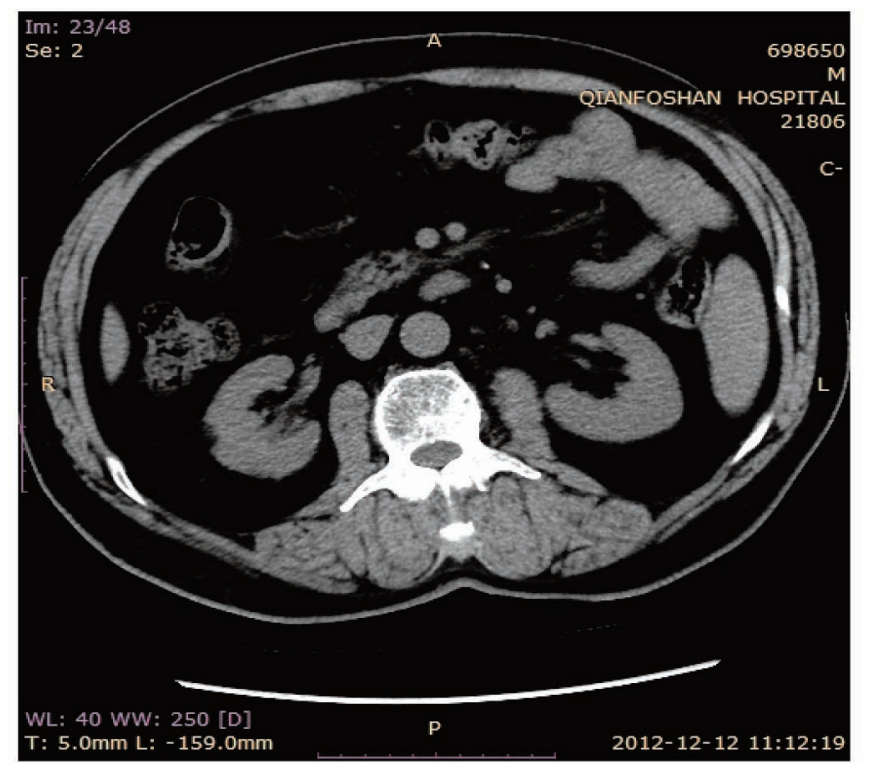

Fig. 5: During the follow-up period, the cyst disappeared and the kidney was restored to its normal shape in 22 of 27 cases.

\section{DISCUSSION}

Because parapelvic cysts are close to the renal hilum and the collecting system, they can lead to obstruction, infection, hypertension, pain and calculus $(7,8)$. Compared with simple renal parenchymal cysts, the parapelvic cyst causes symptoms easier and usually needs surgical intervention, thus its treatment is difficult. The treatment of parapelvic cyst includes paracentesis, sclerotherapy, open operation, unroofing operation by nephroscope, drainage operation and unroofing operation by celoscope.
Paracentesis and sclerotherapy are not suitable for parapelvic cyst treatment because they would lead to haemorrhage by the damage to the hilus renalis structure and urinary fistula of the collective system. The impregnation of a hardener has risk of effusion and can lead to serious pyelonephritis and obstruction of renal pelvis connection $(5,9)$.

Open operation includes the unroofing of the cyst, and nephrectomy. As the traditional standard operation mode, open operation is safe and effective, but the convalescence period is long. The latter favours various minimally invasive techniques gradually (10).

The first case of unroofing of parapelvic cyst by celoscope was reported by Rubenstein in 1993 (11). Whether throughout the pathway of the abdominal cavity or post-peritoneum, the unroofing of the parapelvic cyst by celoscope was considered as one standard technology for parapelvic cyst treatment and its successful results have been previously reported $(12,13)$. Because the position of the parapelvic cyst is usually deep and has close relation to the renal pedicle, operation is difficult and it is easy to damage the collective system and thus lead to the leakage of urine after operation. Camargo et al reported the experience of 42 cases from nine authors who used unroofing operation by celoscope to treat parapelvic cysts; about four cases $(9.5 \%)$ had damage to the collective system (5). For a case where the cyst is completely in the kidney, whether in the renal parenchyma or renal hilum without exposing the cyst, the celoscope is unsuitable.

The pathogenesis of parapelvic cyst is almost the same as the simple kidney cyst. Their content is liquid and the cyst and collective system are separated by a thin membrane; this could offer a base for internal drainage treatment. Percutaneous nephroscopy was first used for the internal drainage treatment by Korth in 1984 (14). Later, this technology was improved by Hulbert (15). Before treating a cyst, it is necessary to have mini-percutaneous nephrostomy; thus, this method is suitable for the situation in which the parapelvic cyst is close to the abdomen and accompanied with renal calculus at the same side. This method is also called the "indirect method". In contrast, the "direct method" is close to the open operation or the cyst unroofing operation by celoscope; it is suitable for the cyst in the back (16). Unfortunately, the possibility of massive haemorrhage, urinary leak and other complications during percutaneous nephroscopy prevents the application of this technology.

Because the urinary system has the special natural orifice, it is possible to treat the parapelvic cyst through the cutting by ureteroscope. In 1991, Kavoussi et al first used this technology for the treatment of peripelvic renal cyst by retrograde ureteroscopic technology using a ureteronephroscope (6). Later, O'Connor et al and Basiri et al repeated this technology successfully $(17,18)$. To date, merely four cases of treatment by this technology exist. Larger numbers and longer follow-up are required. Generally, the possibility of obstruction by the formation of pelvis scar, urinoma, infection by the stagnancy of urine in the cyst, the formation of calculus, 
haematuria, the change of urine composition, and other complications need to be observed closely.

Suitable case selection is important and the enhancement $\mathrm{CT}$ and three-dimensional (3D) reconstruction techniques are also significant for the case diagnosis. Enhancement CT could exactly show the position, size, shape and internal structure, and exclude the cases of tumour. At the same time, 3D reconstruction techniques could define the relationship of the cyst, collective system and vessels of the kidney, and observe the compression of the parapelvic cyst on the collective system and the existence of other tissues between the parapelvic cyst and collective system. This could offer the basis for the approach to operation and avoid damage to the renal hilum tissue.

In this study, the cases of parapelvic cyst accompanied with renal calculus were excluded because we could not access the possibility of infection and tumour with long-term existence of calculus. It is reported that patients with renal cyst are prone to have renal carcinoma because of the precipitate of calcium oxalate crystallization (19). In addition, the pathological change, cell apoptosis and the variation of molecular biological mechanism could be the reasons for carcinoma formation (20-22). For these cases, we combined the unroofing operation by celoscope and stone pulverization by flexible ureteroscopy for treatment.

The exact definition of cyst is the basis of a successful operation. In the ureteroscopy, the compression of the parapelvic cyst on the collecting system could be seen. Based on the observation of cyst by ureteroscopy, there were two kinds of cysts. The first kind of cyst was shown as blue at ureteroscopy and was easy to separate from other parts of the renal pelvis. For the other kind of cyst, the cyst wall was relatively thick and, besides the mark of compression, it had the same colour as other parts of the renal pelvis. For the first kind of cyst, it could be cut out by holmium laser directly. For the other kind of cyst, it was necessary to carefully cut the mucous membrane of the renal pelvis, the tissue under the mucous membrane and the cyst wall step by step in the position with no mark of compression without pulsation in order to avoid damage to blood vessels and the renal parenchyma. Because holmium laser could cut exactly, boil the tissue and coagulate the blood (23), there was no massive haemorrhage, no damage to the kidney and no serious complications.

Besides the above points, the situation of the cyst wall should be observed after entering the cyst, and any suspicious areas should be excluded by tumour biopsy. If some partitions existed in the cyst, they should be cut to avoid recurrence. The results of follow-up showed that cutting of the cyst wall by 1 $\mathrm{cm}$ had a good effect.

Because flexible ureteroscopy is expensive and its life is short, rigid ureteroscopy is used in this work. The results showed that the internal drainage operation for most parapelvic cysts on the collective system could be done by rigid ureteroscopy. In contrast, flexible ureteroscopy was only suit- able for the inferior pole of the kidney and the cyst positions that could not be reached.

The results of follow-up showed that the urine composition and biochemical contents of blood had no change after the drainage of fluid in the collecting system. Also, no infection and calculus related to the stagnating of urine occurred.

\section{ACKNOWLEDGEMENTS}

This work was funded by Shandong Provincial Natural Science Foundation China (Grant No. Y2008C153) and no competing financial interests exist.

\section{REFERENCES}

1. Laucks SP Jr, McLachlan MS. Aging and simple cysts of the kidney. Br J Radiol 1981; 54: 12-4.

2. Amis ES Jr, Cronan JJ. The renal sinus: an imaging review and proposed nomenclature for sinus cysts. J Urol 1988; 139: 1151-9.

3. Kutcher R, Amodio J, Rosenblatt R. Uremic renal cystic disease: value of sonographic screening. Radiology 1983; 147: 833-5.

4. Kutcher R, Mahadevia P, Nussbaum MK, Rosenblatt R, Freed S. Renal peripelvic multicystic lymphangiectasia. Urology 1987; 30: 177-9.

5. Camargo AH, Cooperberg MR, Ershoff BD, Rubenstein JN, Meng MV, Stoller ML. Laparoscopic management of peripelvic renal cysts: University of California, San Francisco, experience and review of literature. Urology 2005; 65: 882-7.

6. Kavoussi LR, Clayman RV, Mikkelsen DJ, Meretyk S. Ureteronephroscopic marsupialization of obstructing peripelvic renal cyst. J Urol 1991; 146: 411-4.

7. Hinman F. Obstructive renal cysts. J Urol 1978; 119: 681-3.

8. Amis ES, Cronan JJ, Pfister RC. The spectrum of peripelvic cysts. Br J Urol 1983; 55: 150-3.

9. Hoenig DM, McDougall EM, Shalhav AL, Elbahnasy AM, Clayman RV. Laparoscopic ablation of peripelvic renal cysts. J Urol 1997; 158: $1345-$

10. Amar AD, Das S. Surgical management of benign renal cysts causing obstruction of renal pelvis. Urology 1984; 24: 429-33.

11. Rubenstein SC, Hulbert JC, Pharand D, Schuessler WW, Vancaillie TG, Kavoussi LR. Laparoscopic ablation of symptomatic renal cysts. J Urol 1993; 150: 1103-6.

12. Roberts WW, Bluebond-Langner R, Boyle KE, Jarrett TW, Kavoussi LR. Laparoscopic ablation of symptomatic parenchymal and peripelvic renal cysts. Urology 2001; 58: 165-9.

13. Yoder BM, Wolf JS. Long-term outcome of laparoscopic decortication of peripheral and peripelvic renal and adrenal cysts. J Urol 2004; 171: 5837.

14. Korth K. Percutaneous, intrarenal marsupialization of renal cysts. In: Percutaneous surgery of kidney stones: techniques and tactics. Berlin: Springer; 1984: 80.

15. Hulbert JC, Hunter D, Young AT, Castaneda-Zuniga W. Percutaneous intrarenal marsupialization of a perirenal cystic collection - endocystolysis. J Urol 1988; 139: 1039-41.

16. Shao ZQ, Guo FF, Yang WY, Wang GJ, Tan SF, Li HL et al. Percutaneous intrarenal marsupialization of symptomatic peripelvic renal cysts: a single-centre experience in China. Scand J Urol 2013; 47: 118-21.

17. O'Connor RC, Guralnick ML, Byrd GF, Murphy MJ, Sulman A. A case report: endoscopic unroofing of symptomatic peripelvic simple renal cyst. J Endourol 2007; 21: 1497-9.

18. Basiri A, Hosseini SR, Tousi VN, Sichani MM. Ureteroscopic management of symptomatic, simple parapelvic renal cyst. J Endourol 2010; 24: $537-40$.

19. Rioux-Leclercq NC, Epstein JI. Renal cell carcinoma with intratumoral calcium oxalate crystal deposition in patients with acquired cystic disease of the kidney. Arch Pathol Lab Med 2003; 127: E89-92.

20. Bastian PJ, Vogel J, Feldmann M, Bastian HP. Papillary renal cell carcinoma within the wall of a solitary renal cyst. Ann Urol (Paris) 2003; 37: $221-2$. 
21. Kovács J, Gomba S. Analysis of the role of apoptosis and cell proliferation in renal cystic disorders. Kidney Blood Press Res 1998; 21: 325-8.

22. Truong LD, Choi YJ, Shen SS, Ayala G, Amato R, Krishnan B. Renal cystic neoplasms and renal neoplasms associated with cystic renal diseases: pathogenetic and molecular links. Adv Anat Pathol 2003; 10: 13559.
23. Matsuoka K, Inoue M, Lida S, Tomiyasu K, Noda S. Endoscopic antegrade laser incision in the treatment of urethral stricture. Urology 2002; 60: $968-72$. 